\title{
Macroeconomic Determinants of Stock Market Performance in Nigeria
}

\author{
Sanya Ogunsakin \\ Department of Economics, Ekiti State University, Ado - Ekiti, Nigeria \\ E-mail: drogunsakinsanya18@gmail.com \\ Isaac Tope Awe (Corresponding author) \\ Department of Economics, Bamidele Olumilua University of Education \\ Science and Technology, Ikere - Ekiti, Nigeria \\ E-mail: awe.isaactope@ coeikere.edu.ng
}

Received: September 11, 2020 Accepted: October 30, 2020 Published: December 1, 2020 doi:10.5296/ber.v10i4.17633

URL: https://doi.org/10.5296/ber.v10i4.17633

\begin{abstract}
This study investigated the macroeconomic determinants of stock market performance in Nigeria between 1985 and 2018. The source of the data for the study were from World Bank Development Indicator, 2020 edition and Central Bank of Nigeria statistical bulletin. The study employed ARDL co-integration approach as estimation technique. Findings from the study showed that inflation rate, real interest rate, real effective exchange rate and world oil price were the major determinants of Nigeria stock market performance during the study period. Based on these findings, the study therefore concludes that both endogeneous and exogeneous macroeconomic variables determine Nigeria stock market performance. Hence, the activities in the global oil market should be monitored in formulating policies to enhance stock market performance in Nigeria.
\end{abstract}

Keywords: Stock market performance, Macroeconomic variable and autoregressive distributed lag.

\section{Introduction}

\subsection{Introduction}

The issue of stock market performance and its impact on macroeconomic stability has received considerable attentions not only among academic researchers but policy makers are 
not left out. This is because, stock market performance is one of the vital instruments of measuring economic well-being of a nation. In view of Obadan (1998), an active stock market contributes to changes in the general level of economic activities. It contributes to the economy directly or indirectly by mobilizing resources from surplus sector of the economy for the benefit of those in need of fund. It mobilizes savings, creation of liquidity, risk diversification, acquisition and dissemination of financial information, and enhanced incentive for corporate control.

The level of stock market and bank development is of the measurements of nation's macroeconomic performance. In some advanced economies like Germany and Japan, banks take leading roles in overseeing the investment decisions of corporates managers, mobilizing savings, capital allocation and management of risk. While in some developed nations as well, notably, England and United States stock market performs function of financial intermediation more than banks. It mobilizes resources to firms, raising capital for investment, exerting corporate control and edging risk management within the economy. Demirguc-Kunt and Levine (1996) Efficient stock markets represent an important and necessary condition for transmission mechanism of monetary policy in every economy.

Africa countries are richly blessed with human and material resources that ordinarily ought to have been annexed and used effectively for the betterment of their economies. But sad to note that this has not been effectively managed to translate to better macroeconomic performance. However, stock market activities have been discovered to be one of the resources that have been underutilized because of unnecessary bureaucracy, wastage and leakages. Their economies are too exposed to external shocks that hinder African investment returns.

The issue of stock market determinants has been a contentious one in recent times. This is because, the fundamental macroeconomic determinants of stock market performance (inflation rate, money supply, real gross domestic product, exchange rate, gross fixed capital formulation, world oil price, foreign interest rate) are not stable. Some of them are so volatile and move exogenously and endogenous to supply and demand conditions. While government and monetary authority may have control over those variables that are determined endogenously they may not likely have influence over exogenous variables. Notably world gross domestic product, foreign interest rate and world oil price.

Nigerian Stock market has experienced remarkable improvement in terms of listed companies, all share price index and market capitalization. Evidence from Central Bank of Nigeria (2018) indicates that market capitalization for 1980s, 1990s and some part of 2000, before global financial crisis that started in England in 2007 were impressive. The Nigerian stock market capitalization stood at $\$ 6.6$ billion in 1985 rose to $\$ 285.8$ billion in 1996 but reduced to \#281.9 billion and $\$ 262.6$ billion in 1997 and 1998 respectively. However, in 1999, it increased again from $\$ 300$ billion to $\$ 13.18$ trillion in 2007 . But due to global financial crisis of 2007, it reduced to $\$ 9.56$ trillion and $\$ 7.03$ trillion in 2008 and 2009 respectively (CBN, 2018). Since then, especially between 2014 and 2018 as reported by the Central bank of Nigeria (2018), the Nigerian stock market recapitalization has been oscillating around $\$ 6.26$ trillion to $\$ 7.42$ trillion. 
In the last few years, the Nigerian macroeconomic performance has not been impressive. The situation is becoming worrisome by the recent reduction in global reduction in crude oil price. The key macroeconomic indicator particularly GDP experienced negative growth rate between 2016 and 2018, this however, brought about decline in the value of naira, high inflation level, balance of payment disequilibrium etc. all these have ability to hinder the growth and development of the stock markets in the country and as well hinder its potential capability in improving development of the country's economy (Azeez \& Obalade, 2019). There have been divergence views as regards the role of macroeconomic variables in determining stock market performance. This is based on the fact that some different in estimation techniques, fundamental determinants are not stable but dynamic, global financial crisis, external shocks such as fluctuation in oil price etc. For instance, Maku and Atanda (2009), Kulathunga (2015), Menike (2014) among others agreed that exchange rate influences stock market performance. While Robert (2008) and Worlu and Omodera (2017) discovered that exchange rate does not exhibit any influence on the stock market performance. So also on the issue of Inflation, Worlu and Omodera (2017), Kiru et al (2014), Ogunniyi (2015) and Floros (2004) found Inflation not to have significant impact on stock in their studies while Menike (2014), Kapingura, Mingiri and Palesa (2016) and Nikmanesh and Nor (2016) established that Inflation impacted significantly on stock.

Furthermore, many emerging economies witness considerable growth in stock markets due to financial liberalization introduced in their economy. Also, financial markets were more related and the risks connected with them are now more linked together (Bhoyu, 2011). However, both emerging and developed financial markets had experienced volatility in the past few years by virtue of the risks associated with macroeconomic variables in the stock market. Also, in the last two decades in Nigeria, there have been various financial sector reforms to enhance their contributions to economic growth. In this regards, the traditional financial services and products delivery have been nearly replaced through financial innovation products. This however, might have led to alteration in the fundamental determinants of stock market performance particularly in Nigeria.

Therefore, the broad objective of this work is to re-examine the macroeconomic determinants of stock market performance in Nigeria by incorporating some exogeneous variables such as: global oil price and world GDP. The rest of the paper is organized thus; this introductory section is followed by section two that presents literature. Section three deals with methods and materials. Section four centres on results and interpretation while section five focuses on discussion.

\subsection{Overview of Stock Market Performance and Nigerian Economy}

Financial sector development is considered to be one of the engines of growth in every economy. However, this depends on commitment of both government and monetary authorities by formulating policies that will stimulate or enhance their performance. Nigerian financial development system places more emphasis on banking sector than other agents of financial intermediation particularly stock market before. However, in the last few decades, more attention has been given to stock market because of its roles in other emerging 
economies. In this regards, the stock market contribution to the overall economic well-being has been impressive before global financial crisis of 2007. Take for instance, Nigerian market capitalization was $\$ 6.6$ billion and all share index was $\$ 117$ billion in 1985 , they both improved gradually to $\$ 180$ billion and $\$ 3.8$ trillion respectively in 1995 . During this period, both inflation and interest rate were high, not stable and reached their peak. There was drastic reduction in inflation from $72.8 \%$ in 1995 to $29.3 \%$ in 1996, this influence stock market positively as market capitalization rose from $\$ 180$ billion in 1995 to $\$ 285.8$ billion in 1996 and all share index also rose from $\$ 3.8$ trillion to $\$ 5.9$ trillion around this period. This can also be attributed to flexible exchange rate system introduced through structural adjustment programme in 1996. All share index and market capitalization witness drastic improvement in 2005 , this is as a result of bank recapitalization that was introduced by government in 2004 which made all share index to increase from $\$ 24.7$ trillion to its peak of \$50.4 trillion in 2008 and market capitalization rose from $¥ 2$ trillion in 2004 to $\$ 13$ trillion in 2007, this period also fell into the period of privatization of some public corporations by the Federal Government.

The improvement in the Nigerian stock market was obstructed by the global financial crises of 2007. This caused reduction in both market capitalization and all share index to $\$ 7$ trillion and $¥ 23$ trillion respectively. This is because some foreign portfolio investors withdrew their capital from Nigeria in order to meet up with the financial obligations in their home countries. The market peaked up in 2010 with all share index of $\$ 24$ trillion and market capitalization of $\$ 9.9$ trillion. Nigeria entered into recession in 2015 which also had negative effect on stock market that led all share index to reduce from $\$ 39.4$ trillion in 2014 to $\$ 30.8$ trillion in 2015. Nigerian economy peaked up in 2017, both all share index and market capitalization were positively influenced. All share index rose from $¥ 30.8$ trillion in 2015 to $\$ 32.2$ trillion and $\$ 37.2$ trillion in 2017 and 2018 respectively.

\section{Literature Review}

\subsection{Empirical Literature}

The relationship between macroeconomic variables and stock market has generated much attention from both academic researchers and policy makers. However, some of these studies are presented to guide and direct the model for this present study.

Acikalin, Aktaş and Unal (2008) investigated the empirical relationship between macroeconomic variables and Istanbul stock markets. The study employed cointegration techniques and vector error correction model (VECM) using quarterly data set and discovered that the relationship between Istanbul stock and four selected macroeconomic variables (i.e. interest rate, exchange rate, gross domestic product and current account balance) was stable at the long run. The result of causality test indicates unidirectional relationships between the selected macroeconomics variables and Istanbul stock index. The study concludes that Istanbul stock, exchange rate, gross domestic product and current account balance have inverse relationship with current changes in ISE index. Furthermore, it is clearly shown that stock market have significant impact on the interest rate but the nature of the impact is not certain. In the same vain, Elly and Oriwo (2012) examined the relationship that exist between 
macroeconomic variables and stock market performance in Kenya with the intention of determined whether changes in macroeconomic variables can be used as a predictive factor for the future of Kenya stock market. In determined the relationship, three macroeconomic variables were examined are inflation rate, lending interest rate and 91-day Treasury bill rate. Autoregressive distributed lag (ARDL) was employed as estimation technique. The findings of their study show that 91-day Treasury bill rate has inverse relationship with the Kenya stock while inflation rate has a weak positive relationship with the Kenya stock. The study concluded that the macroeconomic environment is strongly influence Kenya stock and should be consciously monitored to ensure economic stability.

In a related study, Sangmi and Hassan (2013) examined the interaction between macroeconomic variables and the Indian Stock Market stock price movement using six macroeconomic variables (interest rate, Money Supply, exchange rate, inflation, Industrial production and Gold price). The study made use of monthly data which was estimated by multiple regression. Findings from this study showed that inflation rate has direct relationship with stock price, this implies that an increase in inflation rate will cause an increase in stock price which is higher rate of return. In contrast, exchange rate has inverse relationship with stock price, this also implies that an increase in exchange rate cause lower price of stock which result in lower return. They also discovered that there is a probability of other factor influencing stock price. Also, Forson and Janrattanagul (2014) analysed the long-run equilibrium relationship between the Thailand stock Exchange Index (SETI) and selected macroeconomic variables using error correction model and augumented granger causality test to analyse monthly time series data. In the study, the following macroeconomic variables were employed. They are; interest rate (IR), the consumer price index (CPI), money supply (MS) and gross domestic product \{proxy by the industrial production index (IP) \}. The study findings showed that money supply has strong direct relationship with the Thailand stock index in the long run, in contrast, industrial production index and consumer price index indicate inverse relationship with the Thailand stock index, also in the long-run. They also identified a bi-directional relationship between money supply and industrial production and unidirectional relationships between MS and CPI, IP and CPI, CPI and IR and IP and SETI, it can be inferred that all selected macroeconomic variables are sensitive to Thailand stock market movements. In advancing literature, Baroian (2014) investigated if macroeconomic instability can influence stock market volatility in 5 emerging European countries namely: Poland, Croatia, Hungary, Czech Republic and Romania. The following variables were used: the harmonized index of consumer prices (HICP) proxy for inflation rate, industrial production, exchange rate, and unemployment. The study employed an IGARCH (Integrated GARCH) as estimation technique. Finding from the study showed that the major macroeconomic variable that significantly influences stock market is the exchange rate volatility, with the exception of Romania. The dynamic panel GMM models revealed that the exchange rate volatility is the sole variable that significantly determined the stock market volatility and the relationship is positive. The best explanation for this situation is that, the investors owning foreign currencies may be reluctant to adjust their portfolios whenever exchange rate is volatile and may delay the order placement, reducing the number of transactions which leads to wider spreads and increasing volatility. In addition, Kulathunga 
(2015) investigated the effect of macroeconomic variables on stock market development in Sri Lanka. The study used stock market turnover as proxy for stock market development and the selected macroeconomic variables employed in the study were inflation rate, exchange rate volatility, lending interest rate, deposit interest rate and gross domestic production. Hence, the study discovered that all macroeconomic variables employed influence the stock market development. More precisely, exchange rate and inflation rate associate with higher deposit rate have hampered the stock market development in Sri Lanka. Moreover, positive optimism created by the economic growth and the stock market performance during the previous periods tend to enhance stock market performance.

Also, Kapingura, Mingiri and Palesa (2016) examined the relationship between the stock market and macroeconomic policy variables in South Africa. They employed Johansen cointegration test and the restricted VAR model to analyse the relationship between the stock market and macroeconomic policy variables. The study showed that there is long-run relationship between the selected macroeconomic variables and the stock market in South Africa. The results obtained from the study also showed that changes in inflation rate, money supply, government expenditure, exchange rate and interest rate are transmitted into the stock market. Also, Prempeh (2016) investigated the effect of some macroeconomic variables on stock price volatility in the Ghana Stock Exchange (GSE), annual time series data was employed. Inflation rate, real gross domestic product growth rate and interest rate were the macroeconomic variables used in the study. He employed granger causality technique to determine the causal relationship between stock prices and macroeconomic variables in Ghana. Results obtained from various empirical estimations showed that real domestic product rate granger caused stock price but stock price did not granger cause real domestic product rate. This implies that there is unidirectional relationship and causality running from Real Gross Domestic Product growth rate to stock price. Also from the model, both inflation rate and interest rate did not granger cause stock prices. It is therefore concluded that a shock in real domestic product growth rate influences stock price volatility in Ghana. Duy and Hau (2017) investigated the macroeconomic determinants of share price in the stock market of Vietnam by using a VECM as technique. The results from the study showed that share price index in the stock market of Vietnam was determined by the following macroeconomic variables: exchange rate, money supply, consumer price index and market price index. It also revealed that share price index directly related to money supply and market price index. Increase in economic activities and money supply raised price of stock market. It also indicates that an increase in money supply invariably leads to improvement or development of economy based on that cash flow rises and share price will gain from the expansionary policy. Therefore, increase of money supply in economic activities will bring about improvement in price of stock market. Increase of inflation rate (proxy by CPI) causes reduction in share price of stock market. Likewise, Worlu and Omodero (2017) evaluated the impact of macroeconomic variables on stock market performance in Africa. Four major African countries were investigated: Kenya, Ghana, Nigeria and South Africa, the study employed ordinary least square as estimation technique. The result revealed that there was negative effect of real exchange rate, inflation rate and GDP on stock price index in Nigeria. The result indicated that South Africa's stock market had inverse relationship with inflation 
rate and GDP and no effect of real exchange rate was witness on the stock market. Ghana's stock market has negative with GDP while the others shown no effect. Negative relationship was witness between real exchange rate and Kenyan stock market, but both inflation rate and GDP had no effect on Kenyan stock market.

In a recent development, Boldwin, Faisal, Resatoglu and Türsoy (2018) studied the impact of some macroeconomic variables such as inflation (INF), Money supply growth (M3), and Interest rates (IR) on Johannesburg Stock Exchange. The study employed VECM and granger causality as estimation techniques. Finding from this study showed that all the macroeconomic variables used in the model had significant influence on Johannesburg stock exchange. In advancing literature, Aminullah, Etty, Juniati and Sekar (2019) examined the effect of macroeconomic variables on the stock market in Indonesia. The study made use of multiple regression as estimation technique. Results from various empirical estimations revealed that all the macroeconomic variables employed in the study were found to have positive impact of stock market performance in Indonisia. However, the magnitude of the effect varies. In Nigeria, Maku and Atanda (2009) studied if stock market indicators response to the shocks emanating from macroeconomic variables. The study employed VECM as estimation technique. Finding from the study showed that response of stock market indicators to shocks coming from macroeconomic variables were direct, positive and significant.

Conclusively, the issue of macroeconomic determinants of stock market performance has been a contentious one. There have been divergence views by authors as regards the major macroeconomic variables that actually determine stock market performance. While some scholars submitted that inflation and exchange rate are major determinants, some are of the opinion that majority of determinants are exogenous variables. Therefore, it is pertinent to re-investigate these determinants using both endogeneous and exogeneous macroeconomic variables.

\subsection{Theoretical Underpinning}

In theoretical literature, there are several theories discussing the relationship between macroeconomic variables and financial development. In this study, Arbitrage Pricing Theory (APT) that seems to have close link and relevant to the model of this present study is used to provide empirical background for the study. Rose (1976) developed Arbitrage Pricing Theory (APT) to demonstrate how assets were priced and the risks associated with it. APT is an improved version of capital asset price model (CAPM) by Sharpe (1964). CAPM suggests that asset prices or expected Performance is driven by a single common factor, but Arbitrage Pricing Theory APT advocates that asset prices or expected Performance are driven by multiple macroeconomic factors. The mathematical illustration of the model is presented in equation 1:

$$
R_{i t}=r_{i f}+B_{i} X_{t}+\varepsilon_{t}
$$

Where, $R_{i t}$ which serve as dependent variable is the performance of the individual stock $i$ at time $t, r_{i f}$ is the risk free interest rate or the expected performance at time $t . \quad X_{t}$ is a vector of the predetermined macroeconomic factors or the systematic risks while $B_{i}$ measures the 
sensitivity of the stock to each of macroeconomic factor used in $X_{t}$ while $\varepsilon_{t}$ is the error term, represents unsystematic risk or the premium for risk associated with assets that cannot be diversified, where

$$
\left(\varepsilon_{t} / X_{t}\right)=0, E\left(X_{t}\right)=0 \text {, and } E\left(\varepsilon_{t} \varepsilon_{t} / X_{t}\right)=0
$$

Ross (1976) later advanced this model to show the approximate relationship between the expected performance and the estimated macroeconomic factors in the first step provided that the no arbitrage condition is satisfied, i.e., the expected performance $\mathrm{E}\left(R_{i}\right)$ increases as investors accept more risk, assuming all assets in the market are priced competitively. This relationship can be represented in equation 3 where the estimated macroeconomic factors are used as explanatory variables:

$$
\left(R_{i}\right)=\lambda_{0}+\lambda_{1} \beta_{1 i}+\lambda_{2} \beta_{2 i}+\cdots+\lambda_{n} \beta_{n k}+\mu_{i}
$$

where $R_{i}$,is the mean excess performance for asset $i$ and the $\beta^{\prime} s$ represent the sensitivity of a security's performance $n$ to the risk factor $k$. The $\lambda_{n}$ 's represent the reward for bearing risk associated with the economic factor fluctuations. Equation (3) indicates that the expected performance of an asset is a function of many macroeconomic variables and the sensitivity of the stock to these variables. Many researchers in the literature modify APT model to accommodate more macroeconomic variables and interestingly, the number of macroeconomic variables to be included in the APT model was not specify. Therefore, this study examined the macroeconomic determinants of stock market performance in Nigeria using gross domestic product growth rate, inflation rate, real effective exchange rate, real interest rate, money supply, world oil price and world gross domestic product.

\section{Methodology}

In reference to theoretical underpinning presented from equation 1 to 3 and the modified version of Nikinanesh and Nor (2016) is hereby specified to study the macroeconomic determinants of stock market performance in Nigeria.

$$
\begin{gathered}
\mathrm{LASI}_{t}=\alpha_{0}+\beta_{1} \mathrm{LrGDP}_{t}+\beta_{2} \mathrm{LINF}_{t}+\beta_{3} L M S_{t}+\beta_{4} L R E E X H_{t}+\beta_{5} L I N T_{t}+\beta_{6} L W G D P_{t}+ \\
\beta_{7} L W O P_{t}+\varepsilon_{t}
\end{gathered}
$$

ASI $=$ All Share Index

rGDP $=$ Gross Domestic Product growth rate

$\mathrm{INF}=$ Inflation Rate.

MS = Money Supply

REEXH = Real Effective Exchange Rate.

RINT $=$ Real Interest Rate.

WGDP = World Gross Domestic Product.

WOP $=$ World Oil Price 


\section{Results}

\subsection{Testing the Normality in the Distribution of the Data Set in the Study}

Table 1. Descriptive Statistics

\begin{tabular}{|l|l|l|l|l|l|l|l|l|}
\hline & ASI & INF & MS & REEXR & GDP & RINT & WGDP & WOP \\
\hline Mean & 16202.17 & 19.55235 & $7.06 \mathrm{E}+12$ & 121.4029 & $1.92 \mathrm{E}+11$ & 121.4029 & $4.48 \mathrm{E}+13$ & 42.66588 \\
\hline Median & 10908.47 & 12.15500 & $1.43 \mathrm{E}+12$ & 96.32000 & $8.47 \mathrm{E}+10$ & 96.32000 & $3.42 \mathrm{E}+13$ & 27.30500 \\
\hline Maximum & 50424.70 & 72.84000 & $3.27 \mathrm{E}+13$ & 486.7900 & $5.68 \mathrm{E}+11$ & 486.7900 & $8.64 \mathrm{E}+13$ & 109.4500 \\
\hline Minimum & 117.2833 & 5.380000 & $2.32 \mathrm{E}+10$ & 50.17000 & $2.78 \mathrm{E}+10$ & 50.17000 & $1.28 \mathrm{E}+13$ & 12.28000 \\
\hline Std. Dev. & 15385.90 & 18.14136 & $9.89 \mathrm{E}+12$ & 85.40611 & $1.74 \mathrm{E}+11$ & 85.40611 & $2.30 \mathrm{E}+13$ & 31.31100 \\
\hline Skewness & 0.606603 & 1.653349 & 1.270164 & 2.755258 & 0.751516 & 2.755258 & 0.411352 & 0.944259 \\
\hline Kurtosis & 2.214760 & 4.363251 & 3.280061 & 11.25200 & 2.034262 & 11.25200 & 1.714209 & 2.539784 \\
\hline Jarque-Bera & 2.958664 & 18.12300 & 9.253245 & 139.4869 & 4.521653 & 139.4869 & 3.300975 & 5.352588 \\
\hline Probability & 0.227790 & 0.000116 & 0.009788 & 0.000000 & 0.104264 & 0.000000 & 0.191956 & 0.068818 \\
\hline Sum Sq & 550873.8 & 664.7800 & $2.40 \mathrm{E}+14$ & 4127.700 & $6.54 \mathrm{E}+12$ & 4127.700 & $1.52 \mathrm{E}+15$ & 1450.640 \\
\hline $\begin{array}{l}\text { Sum } \\
\text { Dev. Sq. }\end{array}$ & $7.81 \mathrm{E}+09$ & 10860.59 & $3.23 \mathrm{E}+27$ & 240708.7 & $1.00 \mathrm{E}+24$ & 240708.7 & $1.74 \mathrm{E}+28$ & 32352.50 \\
\hline Observations & 34 & 34 & 34 & 34 & 34 & 34 & 34 & 34 \\
\hline
\end{tabular}

Source: Author computation (2020).

Descriptive statistics result in table 1 helps to predict the nature and behaviour of the data distribution. The arithmetic mean value and median value of world GDP (WGDP) is symmetrical while those of all share index (ASI), inflation (INF), money supply (Ms), real GDP (SCH), real interest rate (RINT) and world oil price (WOP) are asymmetrical in their distribution. If the mean is less than the median, definitely the mode will be greater than the median and such distribution will be negatively skewed using one of the properties of a normal distribution. From the results, it was revealed that ASI, RGDP, WGDP and WOP mirror normal skewness, while INF, MS, REEXR and RINT are positively skewness. Kurtosis result in table 4.1 shows that MS is mesokurtic which depicts normal distribution, while INF, REEXR and RINT are leptokurtic which depicts a peak curve, ASI, RGDP, WGDP and WOP on the other hands are platykurtic which depicts a flatted curve. Jarque-Bera statistic confirmed that ASI, RGDP, WGDP and WOP are normally distributed while INF, MS, REEXH and RINT are not normally distributed.

\subsection{Testing the Correlation among the Series using Correlation Matrix}

Before proceeding to other estimations in the study, it is essential to carry-out a test to ascertain if there is interplay among the variable of interest. This is done through correlation matrix. 
Table 2. Correlation Matrix of Selected Series

\begin{tabular}{|l|l|l|l|l|l|l|l|l|}
\hline & ASI & INF & MS & REEXR & rGDP & RINT & WGDP & WOP \\
\hline ASI & 1.000000 & -0.43269 & 0.716813 & -0.20055 & 0.841263 & -0.20055 & 0.876089 & 0.820111 \\
\hline INF & -0.432691 & 1.00000 & -0.29980 & -0.16851 & -0.40638 & -0.16851 & -0.36404 & -0.39936 \\
\hline MS & 0.716813 & -0.29980 & 1.000000 & -0.11719 & 0.890389 & -0.11719 & 0.917046 & 0.679902 \\
\hline REEXR & -0.200546 & -0.16851 & -0.11719 & 1.000000 & -0.12824 & 1.000000 & -0.23416 & -0.14507 \\
\hline rGDP & 0.841263 & -0.40638 & 0.890389 & -0.12824 & 1.000000 & -0.12824 & 0.951007 & 0.892483 \\
\hline RINT & -0.200546 & -0.16851 & -0.11719 & 1.000000 & -0.12824 & 1.000000 & -0.23416 & -0.14507 \\
\hline WGDP & 0.876089 & -0.36404 & 0.917046 & -0.23416 & 0.951007 & -0.23416 & 1.000000 & 0.845391 \\
\hline WOP & 0.820111 & -0.39936 & 0.679902 & -0.14507 & 0.892483 & -0.14507 & 0.845391 & 1.000000 \\
\hline
\end{tabular}

Source: Author computation (2020).

The result in Table 2 gives us a preliminary idea of the relationship existing among the series. The result indicates that REEXR, INF, REEXH and RINT have negative correlation with ASI while MS, rGDP, WGDP and WOP are positively correlation with ASI.

\subsection{Time Series Properties of the Variable.}

The results of both Phillip Peron (PP) and Augmented Dickey-Fuller (ADF) unit root test presented in Table 4.3 confirm that REEXH and RINT are stationary at level while ASI, rGDP, INF, MS, WGDP and WOP are made stationary at their first difference. The results obtained from both PP and ADF revealed that all the variables are not of the same order of integration, this indicates that Johansen co-integration cannot be used because its condition was not met. Hence, Autoregressive Distributed Lag (ARDL) cointegration procedure developed by Pesaran, Shin and Smith (2001) was employed as the best alternative suggested by Fosu and Magnus (2008).

Table 3. Unit root test

\begin{tabular}{|l|l|l|l|l|l|l|l|}
\hline & \multicolumn{3}{|c|}{ Level } & \multicolumn{3}{c|}{ First Difference } & Order of \\
\cline { 1 - 8 } Variables & $\begin{array}{l}\text { P.P } \\
\text { Statistics }\end{array}$ & $\begin{array}{l}\text { ADF } \\
\text { Statistics }\end{array}$ & $\begin{array}{l}5 \% \text { critical } \\
\text { Value }\end{array}$ & $\begin{array}{l}\text { P.P } \\
\text { Statistics }\end{array}$ & $\begin{array}{l}\text { ADF } \\
\text { Statistics }\end{array}$ & $\begin{array}{l}5 \% \\
\text { Value }\end{array}$ & \\
\hline ASI & -0.8737 & -1.1822 & -2.9540 & -6.2756 & -5.9260 & -2.9571 & $\mathrm{I}(1)$ \\
\hline rGDP & -0.4304 & -0.1866 & -2.9540 & -3.6754 & -3.7329 & -2.9571 & $\mathrm{I}(1)$ \\
\hline INF & -2.6821 & -2.6878 & -2.9540 & -6.5975 & -5.0470 & -2.9571 & $\mathrm{I}(1)$ \\
\hline MS & 5.1980 & 4.1274 & -2.9540 & -3.9690 & -3.8459 & -2.9571 & $\mathrm{I}(1)$ \\
\hline REEXR & -5.8079 & -6.4299 & -2.9540 & -------- & --------- & -------- & $\mathrm{I}(0)$ \\
\hline RINTR & -3.4968 & -4.2244 & -2.9540 & --------- & --------- & -------- & $\mathrm{I}(0)$ \\
\hline WGDP & 0.7022 & 0.8169 & -2.9540 & -4.3781 & -4.3472 & -2.9571 & $\mathrm{I}(1)$ \\
\hline WOP & -1.2608 & -1.2020 & -2.9540 & -4.9225 & -4.9677 & -2.9571 & $\mathrm{I}(1)$ \\
\hline
\end{tabular}

Source: Author computation (2020). 


\subsection{Selection of Appropriate Lag Length}

Table 4. Selection Criteria

\begin{tabular}{|l|l|l|l|l|l|l|}
\hline Lag & LogL & LR & FPE & AIC & SC & HQ \\
\hline 0 & -11.84268 & NA & 0.222724 & 1.322846 & 1.696498 & 1.442380 \\
\hline 1 & 3.358352 & $21.28145^{*}$ & 0.086923 & 0.376110 & 0.796469 & 0.510586 \\
\hline 2 & 5.460784 & 2.803242 & $0.081367^{*}$ & $0.302614^{*}$ & $0.769680^{*}$ & $0.452033^{*}$ \\
\hline 3 & 5.585933 & 0.158522 & 0.087062 & 0.360938 & 0.874710 & 0.525298 \\
\hline 4 & 7.028471 & 1.731045 & 0.085508 & 0.331435 & 0.891914 & 0.510737 \\
\hline
\end{tabular}

Source: Author computation (2020).

The result in table 4 indicates that all the criteria suggest two lag for the model with exception of sequential modify LR. Therefore, two lag variable was selected.

\subsection{Testing the Long-run relationship Among the Series}

The test of co-integration is necessary to establish whether there is long run relationship among the variables. The appropriate co-integration test is the Bound test proposed by Pesaran et al (2001) which is adopted and result presented in table 5.

Table 5. Co-integration Bound Test for ASI

\begin{tabular}{|l|l|l|}
\hline F- Statistic 7.8853 & & \\
\hline Level of Significance & $\mathrm{I}(0)$ Bound & $\mathrm{I}(1)$ Bound \\
\hline $10 \%$ & 1.92 & 2.89 \\
\hline $5 \%$ & 2.17 & 3.21 \\
\hline $2.5 \%$ & 2.43 & 3.51 \\
\hline 2.73 & 3.06 & 3.9 \\
\hline
\end{tabular}

Source: Author's Computation, (2020)

Table 5 indicates that the estimated model for ASI establishes that long-run relationship is found in the bound test. Since, the calculated F-statistic value of 7.8853 is greater than the critical values for the upper bound even at $1 \%$ significant level. Based on this, the study confirms that there is evidence of long-run relationship among the variables of interest. Following this Bound test result, the study proceeds to estimate ARDL for both short run long run dynamism. 


\section{Macrothink}

Table 6. Long Run Analysis Result

\begin{tabular}{|l|l|l|l|l|}
\hline \multicolumn{2}{|l|}{ Dependent Variable: ASI } & & \\
\hline Variable & Coefficient & Std. Error & t-Statistic & Prob. \\
\hline C & 8.163932 & 21.65788 & 0.376950 & 0.7115 \\
\hline ASI(-1) & 0.580209 & 0.257925 & 2.249523 & 0.0399 \\
\hline ASI(-2) & 0.055550 & 0.219799 & 0.252732 & 0.8039 \\
\hline rGDP(-1) & 0.347463 & 0.464559 & 0.747942 & 0.4661 \\
\hline rGDP(-2) & 0.629730 & 0.433407 & 1.452974 & 0.1668 \\
\hline REEXR(-1) & -0.329322 & 0.246595 & -1.335477 & 0.2016 \\
\hline REEXR(-2) & -0.127509 & 0.211181 & -0.603791 & 0.5550 \\
\hline INF(-1) & -0.014760 & 0.006756 & -2.184798 & 0.0452 \\
\hline INF(-2) & 0.003878 & 0.005504 & 0.704529 & 0.4919 \\
\hline MS(-1) & 0.291760 & 0.537862 & 0.542445 & 0.5955 \\
\hline MS(-2) & 0.156629 & 0.458176 & 0.341853 & 0.7372 \\
\hline RINT(-1) & -0.017548 & 0.008679 & -2.021847 & 0.0614 \\
\hline RINT(-2) & -0.015350 & 0.008924 & -1.720125 & 0.1060 \\
\hline WGDP(-1) & 0.617331 & 1.857484 & 0.332348 & 0.7442 \\
\hline WGDP(-2) & -0.844531 & 1.393763 & -0.605936 & 0.5536 \\
\hline WOP(-1) & -0.608627 & 0.341209 & -1.783736 & 0.0947 \\
\hline WOP(-2) & 0.436224 & 0.323123 & 1.350026 & 0.1970 \\
\hline R-squared & 0.991135 & & & \\
\hline Adjusted R-squared & 0.981679 & & & \\
\hline F-statistic & 104.8155 & & & \\
\hline Prob(F-statistic) & 0.000000 & & & \\
\hline Durbin-Watson stat & 2.191483 & & & \\
\hline & & & & \\
\hline
\end{tabular}

Source: Author's Computation, (2020)

The result on table 6 showed that inflation rate, real interest rate and world oil price have significant impact on Nigeria stock market performance in the long run and they exhibit negative impact. This indicates that inflation rate, real interest rate and world oil price have negative impact on stock market performance in Nigeria. Gross domestic product, real effective exchange rate, money supply and world gross domestic product does not significantly impacted on stock market performance (ASI) at the long run. The value of $\mathrm{R}^{2}$ of 0.99 shows that the selected macroeconomic variables explained about $99 \%$ of the variation in the dependent variable (ASI), therefore, macroeconomic variables significantly determine stock market performance in Nigeria at long run. 
4.6 The Short-run Dynamic Relationship among the Series

Table 7. Error Correction Model (ECM) result

\begin{tabular}{|l|l|l|l|l|}
\hline Dependent Variable: D(ASI) & & \\
\hline Variable & Coefficient & Std. Error & t-Statistic & Prob. \\
\hline C & 0.055432 & 0.148990 & 0.372052 & 0.7158 \\
\hline D(ASI(-1)) & 0.806770 & 0.211624 & 3.812273 & 0.0022 \\
\hline D(ASI(-2)) & -0.218598 & 0.199324 & -1.096694 & 0.2927 \\
\hline D(rGDP(-1)) & 0.232894 & 0.394300 & 0.590653 & 0.5649 \\
\hline D(rGDP(-2)) & 0.456204 & 0.336887 & 1.354172 & 0.1988 \\
\hline D(REEXR(-1)) & -0.421310 & 0.176790 & -2.383117 & 0.0331 \\
\hline D(REEXR(-2)) & 0.003386 & 0.163174 & 0.020752 & 0.9838 \\
\hline D(INF(-1)) & -0.013213 & 0.005570 & -2.372257 & 0.0338 \\
\hline D(INF(-2)) & 0.008056 & 0.004150 & 1.941011 & 0.0743 \\
\hline D(MS(-1)) & 0.504251 & 0.370132 & 1.362357 & 0.1962 \\
\hline D(MS(-2)) & 0.313790 & 0.515692 & 0.608484 & 0.5534 \\
\hline D(RINT(-1)) & -0.017272 & 0.006568 & -2.629907 & 0.0208 \\
\hline D(RINT(-2)) & -0.009923 & 0.006170 & -1.608156 & 0.1318 \\
\hline D(WGDP(-1)) & 0.880986 & 1.591499 & 0.553557 & 0.5893 \\
\hline D(WGDP(-2)) & -0.988952 & 1.287021 & -0.768404 & 0.4560 \\
\hline D(WOP(-1)) & -0.575106 & 0.348228 & -1.651519 & 0.1226 \\
\hline D(WOP(-2)) & -0.728762 & 0.322278 & -2.261285 & 0.0415 \\
\hline ECM2(-1) & -1.342121 & 0.343286 & -3.909635 & 0.0018 \\
\hline R-squared & 0.797660 & & & \\
\hline Adjusted R-squared & 0.533060 & & & \\
\hline F-statistic & 3.014597 & & & \\
\hline Prob(F-statistic) & 0.024651 & & & \\
\hline Durbin-Watson stat & 2.160903 & & & \\
\hline & & & & \\
\hline
\end{tabular}

Source: Author's Computation, (2020)

It is clearly revealed in the table 7 that real effective exchange rate, inflation rate, real interest rate and world oil price have significant impact on Nigeria stock market performance in the short run. Real effective exchange rate, inflation rate, real interest rate and world oil price are negatively related to stock market performance while gross domestic product, money supply and world gross domestic product does not significantly impact on stock market performance (ASI) at the short run. The coefficient of the ECM is significant with the appropriate (negative) sign as revealed on table 7. Significance of the ECM confirmed the existence of long run equilibrium relationship between stock market performance and the selected macroeconomic variables. This shows a stable error which eventually converges to the long run equilibrium when there is a disequilibrium from short run equilibrium level, hence, the negative coefficient of the ECM indicates the existence of long run equilibrium relationship of the model. The $\mathrm{R}^{2}$ value of 0.79 indicates that the selected macroeconomic variables explained about $79 \%$ of the variation in the dependent variable (ASI). Therefore, macroeconomic variables significantly determine stock market performance in Nigeria at short run. 


\subsection{Testing for Structural Stability}

In order to test for the stability of the model used in this paper, the cumulative sum of the recursive residuals (CUSUM) and the cumulative sum of squares is applied. The test finds parameters instability if the plots of the cumulative sum of the recursive residuals (CUSUM) and the cumulative sum of squares go outside the area between the two critical lines. The plots are shown in figures 1 and 2 below:

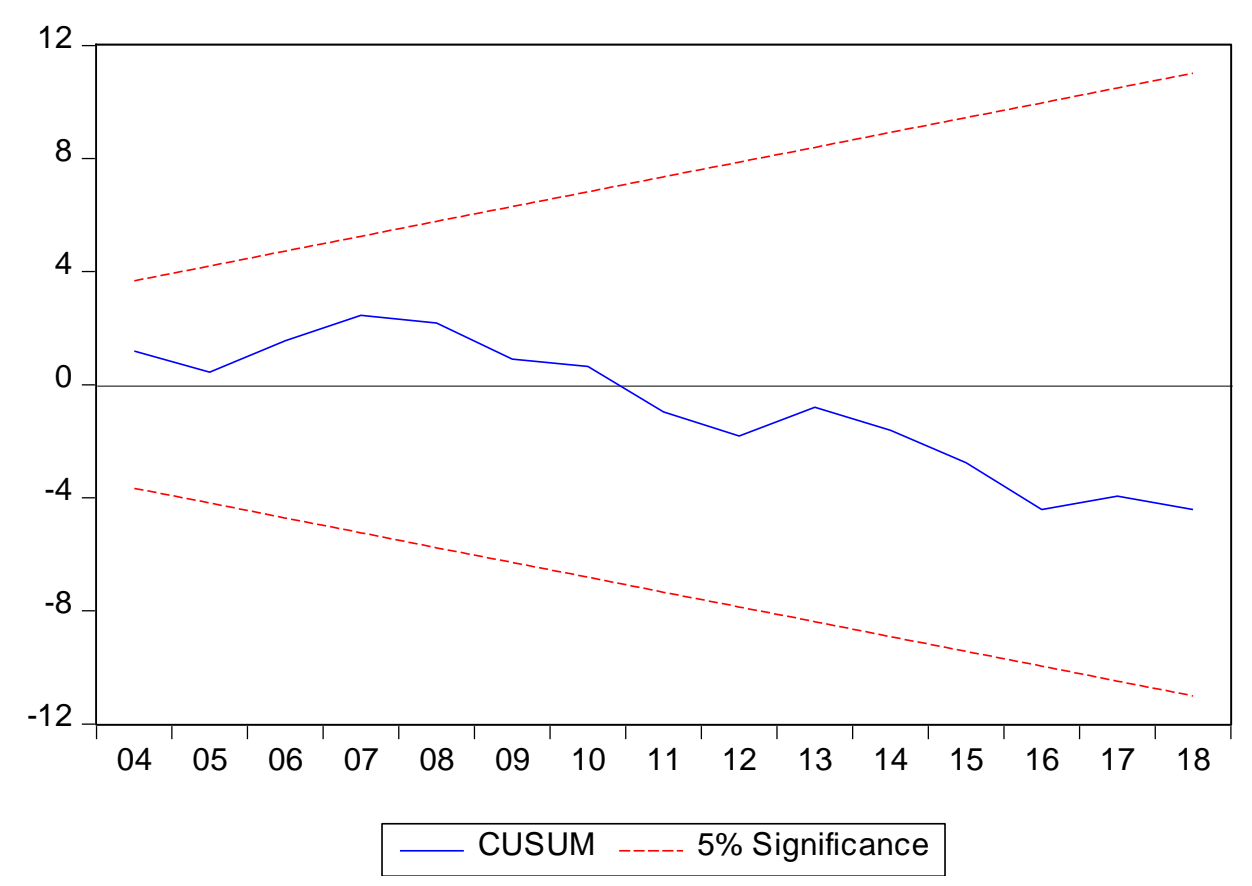

Figure 1. CUSUM Test for Structural Stability of the Parameters

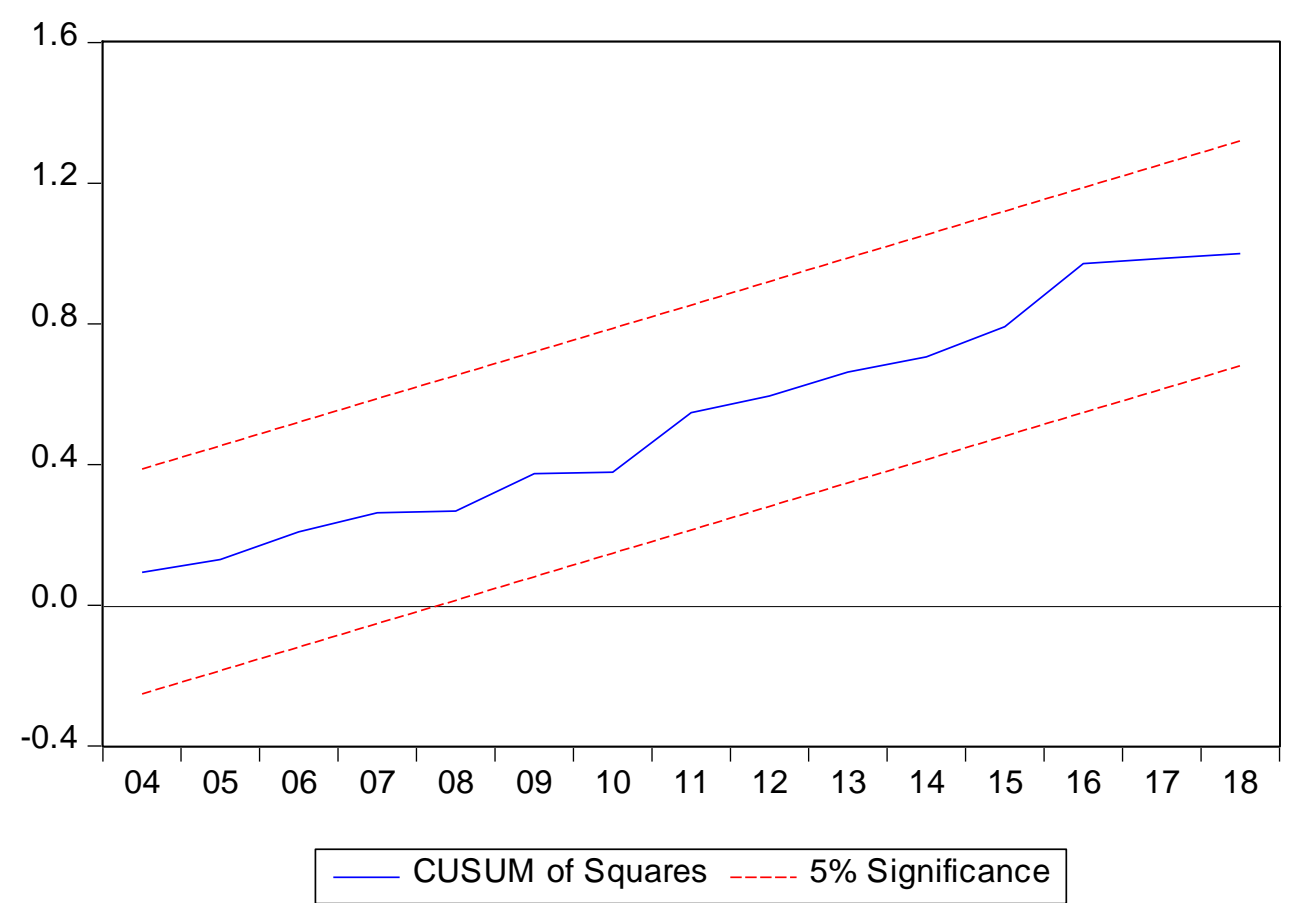

Figure 2. CUSUM of Squares Test for Structural Stability of the Parameters 
As shown in fig 1 and fig.2, the results are suggestive of coefficient stability since the plots did not move outside the 5\% critical bound. This confirms the existence of coefficient stability for the estimated parameters for the short run dynamics and long run of all share index function over the sample periods as the results indicate tendency of further coefficients stability.

\section{Discussion}

The study reveals that gross domestic product has positive but insignificant effect on stock market performance in Nigeria both in the short run and long run. The positive relationship effect indicates that there is direct relationship GDP and stock market performance in Nigeria. This implies that an increase in GDP will result to an increase in national disposable income and therefore more retail investment in the stock market. The result is consistent with the study of Nishat and Shaheen (2004), Ratanapokorn and Sharma (2007), Emmanuel and Samuel (2009) and Hsing (2011) that observed positive relation between real GDP and stock market in their studies. Conversely, the finding did not agree with Gan, Lee, Yong and Zhang (2006) and Maku and Atanda (2010) who revealed that real GDP significantly affect movements in the stock market and that real output consistently determine stock market performance.

Exchange rate has negative but significant effect on stock market performance in Nigeria only in the short run. This is in consonance with the findings of Grambovas (2003), Serife and Ugur (2012) and Abubakar and Dantama (2017) who affirmed that exchange rate has significant influence on stock prices. This finding is contrary to that of Hsing (2011); Izedomine and Abdullahi (2011); Mgbame and Chijoke-Mgbame (2013) and Aigbovo and Izekor (2015) who affirmed that exchange rate has no significant effect on stock prices.

Inflation rate has negative but significant effect both in the short run and long run on all share index. The explanation for this negative relationship supports the proxy effect of Fama (1981) who opined that an increase in the production cost is caused by higher inflation which adversely affects the level of real economic activity and investment profitability; since the real economic activity has direct impact on stock return, an increase in inflation will adversely affect the stock price. The result is in agreement with Sharpe (2002), Maku and Atenda (2009), Khumalo (2013) and Worlu and Omodero (2017) that discovered negative influence of inflation on stock market. While Elly and Oriwo (2012) and Boldwin et al (2018) maintained in their empirical analysis that inflation has positive effects on stock market.

Money supply has positive but insignificant effect on stock market performance in Nigeria at the short run and long run. This can be argued that an increase in the money supply acts as an economic stimulus, invariably increase cash flows (the corporate earnings effect) and increase stock prices. This result is tandem with the works of Maysami and Koh (2000), Kwanchanok (2000), Brahmasrene and Jiranyakul (2007), Shaoping (2008) and Duy and Hau (2017) who have identified positive relationships between money supply and stock price. The findings indicate that a rise in money supply leads to the development of economy based on the fact that there is a rise in cash flow and the share price will get benefits from the expansionary policy. This study negates the findings of Ratanapakorn and Shama (2007); 
Ibrahim and Aziz (2003); Osamwonyi and Evbayiro-Osagie (2012); and Aigbovo and Izekor (2015) who discovered inverse relationship between money supply and stock price.

Interest rate has negative but significant effect on stock market performance in both short run and long run. This indicates that as the interest rate increases, investors tend to reduce their investment in stock and more in other investment assets, causing fall in stock prices. Kwanchanok (2000), Bernanke and Kuttner (2005), Seema and Paresh (2012) and Forson et al (2013) agreed that interest rates have negative relationships with stock prices. However, Nwokoma (2002), Ologunde, Elumilade and Asaolu (2006) and Aigbovo and Izekor (2015) discovered positive influence of interest rate on stock market.

World gross domestic product did not produce any effect on the stock market performance in Nigeria both in the short run and long run. It ought to have effect on Nigeria stock market performance, since, the country imports manufactured goods from developed and emerging countries. Therefore, World GDP is expected to have indirect impact on Nigeria stock market through their influence on the prices of imported products and often cause inflationary pressure (imported inflation) on the economy which could perfectly determine interest rates and investment in the future.

World oil price is inversely and significantly related to stock market index at both short-run and long-run. The inverse relationship is expected between oil prices and stock markets in most net-oil importing countries like Nigeria. Nigeria usually imports manufactured goods from developed countries, this allowed oil price influence on the prices of imported products. Also, increase in the price of oil are often translates to inflationary pressure and the future of interest rates. This indicates that world oil price is inversely related to stock market performance. This is at variance with study of Arouri and Rault (2009)

Finally, the study also revealed that there is existence of a strong long run equilibrium relationship between stock market performance and the macroeconomic variables used in the study. This clearly indicates that there will be converges to the long run equilibrium whenever is a state of disequilibrium from short run equilibrium level. This study is however able to discover that oil price has influence on stock market performance in Nigeria. The study also discovered that the major determinants of stock market performance in Nigeria during the study period are real effective exchange rate, inflation rate, real interest rate and world oil price. Based on these findings, the study therefore concludes that both endogeneous and exogeneous macroeconomic variables determine stock market performance in Nigeria. Hence, the activities in the global oil market should be monitored in formulating policies to enhance stock market performance.

\section{References}

Acikalin, S., Aktaş, R., \& Unal, S. (2008). Relationships between Stock Markets and Macroeconomic Variables: an Empirical Analysis of the Istanbul Stock Exchange. Investment Management and Financial Innovations, 5(1), 8-16.

Aigbovo, O., \& Izekor, A. O. (2015). The impact of macroeconomic variables on stock market index in Nigeria. African Journal of Management Sciences (AJMS), 1(1), 18-39. 
Aminullah, A., Etty, M., Juniati, G., \& Sekar, M. (2019). The Effect of Macro Economic Variables on Stock Return of Companies That Listed in Stock Exchange: Empirical Evidence from Indonesia. International Journal of Business and Management, 14(8), 108. https://doi.org/10.5539/ijbm.v14n8p108

Arouri, M. E. H., \& Rault, C. (2009). Oil prices and stock markets: what drives what in the gulf corporation council countries? William Davidson Institute Working Paper No. 960.

Azeez, B. A., \& Obalade, A. A. (2019). Macroeconomic Determinants of Stock Market Development in Nigeria: (1981-2017). Acta Universitatis Danubius. Economica, 15(1), 203-216.

Baroian, E. (2014). Can Macroeconomic Volatility affect Stock Market Volatility? The case of 5 Central and Eastern European Countries. Romanian Journal of Fiscal Policy, 5(2), 41-55.

Bhoyu, P. (2011). Macroeconomic relationship in Indonesia stock market. Evidence on Cointegration: Georgia state university.

Boldwin, N., Faisal, F., Resatoglu, N. G., \& Türsoy, T. (2018). The Impact of Macroeconomic Variables on Stock Returns: A Case of the Johannesburg Stock Exchange. Romanian Statistical Review, 2, 87-104.

Brahmasrene, T., \& Jiranyakul, K. (2007). Cointegration and causality between stock index and macroeconomic variables in an emerging markets. Academy of Acounting and Financial Studies Journal.

Demirguc-Kunt, A., \& Levine, R. (1996). Stock Market, Corporate Finance and Economic Growth: An Overview. The World Bank Review, 10(2), 223-239. https://doi.org/10.1093/wber/10.2.223

Elly, O. D., \& Oriwo, A. E. (2012). The Relationship between Macro Economic Variables and Stock Market Performance in Kenya. DBA Africa Management Review, 3(1), 38-49.

Emmanuel, E. D., \& Samuel, O. A. (2009). An Impact Analysis of Real Gross Domestic Product Inflation and Interest Rates on Stock Prices of Quoted Companies in Nigeria. International Research Journal of Finance and Economics, 25.

Fama, E. F. (1981). Stock Returns, Real Activity, Inflation, and Money, American Economic Review, 71(4), 545-565.

Floros, C. (2004). Stock Returns and Inflation in Greece. Applied Econometrics and International Development. AEEADE, 4(2).

Forson, J. A., Jakkaphong, J., \& Carsamer, E. (2013). Culture Matters: A Test of Rationality on Economic Growth. Asian Social Science, 9(9). https://doi.org/10.5539/ass.v9n9p287

Fosu, O. E., \& Magnus, F. J. (2008). Aggregate Import Demand and Expenditure Components in Ghana. Journal of Social Sciences, 4(1), 1-6.

https://doi.org/10.3844/jssp.2008.1.6 
Gan, C., Lee, M., Yong, H., \& Zhang, J. (2006). Macroeconomic Variables and Stock Market Interactions: New Zealand Evidence. Investment Management and Financial Innovations, 3(4), 89-101.

Grambovas, C. A. (2003). Exchange rate volatility and equity markets. Eastern European Economics, 41, 24-48. https://doi.org/10.1080/00128775.2003.11041057

Hsing, Y. (2011). The stock market and macroeconomic variables in a BRICS countries and policy implications. International Journal of Economics and Financial Issues, 1(1), 12-18.

Ibrahim, M. H., \& Aziz, H. (2003). Macroeconomic variables and the Malaysian equity market: A view through rolling subsamples. Journal of Economic Studies, 30(1), 6-27. https://doi.org/10.1108/01443580310455241

Kapingura, K., Mingiri, N. F., \& Palesa, M. M. (2016). The Interaction between the Stock Market and Macroeconomic Policy Variables in South Africa. J Economics, 7(1), 1-10. https://doi.org/10.1080/09765239.2016.11907815

Khumalo, J. (2013). Inflation and Stock Prices Interactions in South Africa: VAR Analysis. International Journal of Economics and Finance Studies, 5(2).

https://doi.org/10.5901/mjss.2013.v4n13p415

Kirui, E., \& Wawire, N. H. W. (2014). Macroeconomic Variables, Volatility and Stock Market Returns: A Case of Nairobi Securities Exchange, Kenya. International Journal of Economics and Finance, 6(8), 214-228. https://doi.org/10.5539/ijef.v6n8p214

Kulathunga K. M. M. C. B. (2015). Macroeconomic Factors and Stock Market Development: With Special Reference to Colombo Stock Exchange. International Journal of Scientific and Research Publications, 5(8).

Kwanchanok, T. (2000). The relationship between SET Indices and the Macroeconomic Indicators. Chiang Mai University, Thailand.

Maku, O. E., \& Atanda, A. A. (2009). Does Macroeconomic Indicators exert shock on the Nigerian Capital Market? Munich Personal RePEc Archive. [Online] Available:

http://mpra.ub.uni-muenchen.de/17917/

Maku, O. E., \& Atanda, A. A. (2010). Determinants of Stock Market Performance in Nigeria: Long Run Analysis. Journal of Management and Organizational Behaviour, 1(3), 1-16.

Maysami, R. C., \& Koh, T. S. (2000). A vector error correction model for the Singapore stock market. International Review of Economics and Finance, 9, 79-96.

https://doi.org/10.1016/S1059-0560(99)00042-8

Menike, L. M. C. S. (2006). The Effect of Macroeconomic Variables on Stock Prices in Emerging Sri Lankan Stock Market. Sabaragamuwa University Journal, 6(1), 50-67. https://doi.org/10.4038/suslj.v6i1.1689

Mgbame, C. O., \& Chijoke-Mgbame, A. M. (2013). Macroeconomic Variables and Stock Returns in the Nigerian Capital market. Benin Journal of Social Sciences, 21(1), 193-204. 
Nikmanesh, L., \& Nor, A. H. S. M. (2016). Macroeconomic determinants of stock market volatility: an empirical study of Malaysia and Indonesia. Asian Academy of Management Journal, 21(1), 161-180.

Nishat, M., \& Shaheen, R. (2004). Macroeconomic Factors and Pakistani Equity Market. The Pakistani Development Review, 43(4), 619-637. https://doi.org/10.30541/v43i4IIpp.619-637

Nwokoma, N. I. (2002). Stock market performance and macroeconomic indicators nexus in Nigeria: An Empirical Investigation. NJESS, 44(2), 44-51.

Obadan, M. I. (1998). Presidential Address presented on the "Capital Market and Nigeria's Economic Development" at one day seminar organized by Nigeria Economic Society at the Institute of International Affairs, Lagos.

Ologunde, A. O., Elumilade, D. O., \& Asaolu, T. O. (2006). Stock Market Capitalization and Interest Rate in Nigeria: A Time Series Analysis. International Research Journal of Finance and Economics, 4, 154-167.

Omorokunwa, O. G., \& Ikponmwosa, N. (2014). Macroeconomic Variables and Stock Price Volatility in Nigeria. Annals of the University of Petroşani, Economics, 14(1), 259-268.

Osamwonyi, I. O., \& Evbayiro-Osagie, E. I. (2012). The relationship between macroeconomic variables and stock market index in Nigeria. Journal of Economics, 3(1), 55-63. https://doi.org/10.1080/09765239.2012.11884953

Oseni, I. O., \& Nwosu, P. I. (2011). Stock Market Volatility and Macroeconomic Variables Volatility in Nigeria: An Exponential GARCH Approach. Journal of Economics and Sustainable Development, 2(10), 28-42.

Pesaran, H. M., Shin, Y., \& Smith, R. J. (2001). Bounds Testing Approaches to the Analysis of Long-run relationships. Journal of Applied Economics, 16, 289-326.

https://doi.org/10.1002/jae.616

Prempeh, K. B. (2016). Macroeconomic Variables and Stock Price Volatility in Ghana. [Online] Available: https://mpra.ub.uni-muenchen.de/70545/

Ratanapakorn, O., \& Sharma, S. C. (2007). Dynamics analysis between the US stock return and the macroeconomics variables. Applied Financial Economics, 17(4), 369-377.

https://doi.org/10.1080/09603100600638944

Robert, D. G. (2008). Effect of Macroeconomic variables on stock market returns for four emerging economies: Brazil, Russia, India and China. International Business, Economics Research Journal, 7(3).

Ross, S. A. (1976). The arbitrage theory of capital asset pricing. Journal of Economic Theory, 13(3), 341-360. http://dx.doi.org/10.1016/0022-0531(76)90046-6

Sangmi, P. M. U. D., \& Hassan, M. M. (2013). Macroeconomic Variables on Stock Market Interactions: The Indian Experience. IOSR Journal of Business and Management, 11(3), 15-28. https://doi.org/10.9790/487X-01131528 


\section{Macrothink}

Business and Economic Research

ISSN 2162-4860 2020, Vol. 10, No. 4

Seema, N., \& Paresh, K. N. (2012). Do US macroeconomic conditions affect Asian stock markets?. Journal of Asian Economics, 23, 669-679.

https://doi.org/10.1016/j.asieco.2012.05.001

Serife, O., \& Ugur, E. (2012). Macroeconomic Factors and Stock Returns. International Journal of Academic Research in Business and Social Sciences, 2(9), 315-343.

Shaoping, C. H. (2008). Positivist analysis on effect of monetary policy on stock price behaviours. Proceedings of 2008 conference on regional economy and sustainable development.

Sharpe, S. A. (2002). Re-examining Stock Valuation and Inflation: The Implications of Analysis Earnings Forecasts. Review of Economics and Statistics, 84, 632-648.

https://doi.org/10.1162/003465302760556468

Sharpe, W. F. (1964). Capital asset prices: A theory of market equilibrium under conditions of risk. The Journal of Finance, 19(3), 425-442.

https://doi.org/10.1111/j.1540-6261.1964.tb02865.x

Worlu, C. N., \& Omodero, C. O. (2017). A Comparative Analysis of Macroeconomic Variables and Stock Market Performances in Africa (2000-2015). International Journal of Academic Research in Accounting, Finance and Management Sciences, 7(4), 95-102. https://doi.org/10.6007/IJARAFMS/v7-i4/3436

\section{Copyright Disclaimer}

Copyright for this article is retained by the author(s), with first publication rights granted to the journal.

This is an open-access article distributed under the terms and conditions of the Creative Commons Attribution license (http://creativecommons.org/licenses/by/4.0/). 